\title{
Philomela angelica Daniela Speera \\ - k neznámemu dielu známeho hudobníka
}

\section{Philomela Angelica by Daniel Speer - an Unknown Work of a Well-known Musician}

Jana Kalinayová-Bartová / jana.bartova@uniba.sk

Katedra muzikológie FF UK, Bratislava, SK

\begin{abstract}
Philomela Angelica Cantionum Sacrarum by Daniel Speer is one of the lesser known works of this famous Silesian musician, music theoretician, writer and composer. The collection, which contains 24 small-scale sacred concertos (or concertant motets) with Latin biblical and original period religious texts, was printed in an unknown printing house in 1688 . This study comprises the results of research of the music published in this collection which show direct inspiration sources based on the repertoire of the Milan motet of the 1640 s. Criticism regarding the source has also raised other questions related to the true origin of this collection, its period reception and extreme popularity in the musical centers of the 17th century on the territory of present day Slovakia, as well as the issues related to solo motet style transformations and regional customs in instrumentation practice.
\end{abstract}

\section{Key words}

Daniel Speer, Milanese motet, small-scale sacred concerto, stile concertato 
Snahou azda každého hudobného historika je hudbu, ktorou sa zaoberá, poskytnút širšej kultúrnej komunite a umožnit, aby umelecky hodnotné diela dávno zabudnutých skladatelov boli nielen predmetom diskusií úzkeho okruhu špecialistov, ale aj znovu ožili pred širšou verejnostou na koncertných pódiách. Jedným z predpokladov k naplneniu tohto ciela je publikovanie kritických pramenných notových edícií, ktoré sa však nie lahko dostávajú do edičných plánov profesionálnych hudobných vydavatelstiev. Staré dôvody bývalého režimu s ideologickým embargom na sakrálnu hudbu nahradili nové, trhové, obava vydavatel'stiev, že takéto edície nebudú ekonomicky úspešné, a tak ani dnes nie je situácia ideálna. Kritická notová edícia súborného diela Adama Michnu, ktorá reprezentuje d’alšiu oblast̉ bohatej vedeckej činnosti profesora Sehnala, aj napriek všetkým peripetiám, ktoré ju sprevádzajú, ${ }^{1}$ je ale bez pochýb významným edičným činom a prameňom inšpirácie či poučenia pri realizácii iných podobných zámerov. Som rada, že môžem na tomto mieste, pri príležitosti vzácneho jubilea profesora Sehnala, predstavit jeden takýto projekt, a to štúdium skladatelského odkazu Daniela Speera prostredníctvom jeho zbierky sakrálnych skladieb Philomela angelica cantionum sacrarum (1688) a prípravu jej pramenno-kritického notového vydania.

Vzhladom na iba prechodné a anonymné pôsobenie Daniela Speera na území Slovenska nezanechal umelecký odkaz tohto hudobníka v hudobno-kultúrnej minulosti Slovenska takú významnú stopu akú zanechal Adam Michna v českej hudobnej kultúre, predsa len tento sliezsky hudobník, hudobný teoretik, spisovatel', cestovatel', rodák z Wroclavu, už desatročia púta pozornost̉ slovenských hudobných historikov vd’aka jeho hudobnej aj písomnej reflexii reálií dobového hudobného života a praxe v hudobných centrách Slovenska. Pri spätnom pohlade na jeho novodobú hudobnohistorickú reflexiu sa ponúka istá paralela s históriou reflexie Michnu: aj Speer sa spomína v každej publikácii a lexikóne, ale podobne, ako bol Michna dlho vnímaný ako „pesničkár“,2 tak aj Speer dlho ostával vo vedomí hudobných historikov ako „tančekár“. Laická, ale i odborná verejnoste totiž Speerovo hudobné dielo pozná hlavne cez cyklus epicko-dramatických quodlibetov a štylizovaných dobových tancov západo- aj východoeurópskeho pôvodu, ktorý Speer publikoval pod názvom Hudobný turecký Eulenspiegel (Musicalisch-Türkischer Eulen-Spiegel) v Ulme roku 1688, ${ }^{3}$ prípadne sa jeho meno spája so „Štvorlístkom“ - hudobno-teoretickým kompendiom v štyroch kapitolách (...Vierfaches Musicalisches Kleeblatt, 1697), ${ }_{4}^{4}$ obsa-

\footnotetext{
1 SEHNAL, Jiří. Adam Michna z Otradovic - skladatel. Olomouc: Univerzita Palackého, 2013, s. 5-6.

2 Tamtéž, s. 5.

3 Dielo Speer publikoval pod pseudonymom Dacianischer Simplicissimus in Güntz (dnes Közseg v Mad’arsku), ale najnovšie podla Dünnhaupta ho vytlačili v tlačiarni Matthaeusa Wagnera v Ulme. DÜNNHAUPT, Gerhardt. Daniel Speer (1636-1707). In: Personalbibliographien zu den Drucken des Barock. Band 6., 2.vyd. Stuttgart: Anton Hiersemann Verlag, 1993, s. 3939-3950. Moderná kritická notová edícia Hudobného tureckého Eulenspiegla vyšla vo vydavatel'stve OPUS v 5 zväzkoch v rokoch 1971-1992. Na edičnej príprave sa podiel’ali Alexander Móži, Ján Albrecht a Luba Ballová.

4 Traktát vyšiel dvakrát. Staršia verzia s názvom Grundrichtiger, kurtz, leicht und nöthiger Unterricht der musikalischen Kunst, wie man füglich und in kurtzer Zeit Choral und Figural singen, den General-Baß tractiren und componiren lernen soll vyšla roku 1687 v Ulme. Druhá, rozšírená verzia pod plným názvom Grundrichtiger KurtzLeicht-und Nöthiger jetzt Wol-vermehrter Unterrich der Musicalischen Kunst. Oder Vierfaches Musicalisches Kleeblatt bola publikovaná na tom istom mieste o desat rokov neskôr.
} 
hujúcim aj praktické cvičenia pre vyučovanie hry na rozličných hudobných nástrojoch. V hudobnom odkaze Speera má však pomerne vel'ké zastúpenie aj viachlasná sakrálna tvorba, ktorej sa donedávna venovalo len málo pozornosti a až v posledných rokoch sa záujem obracia na hlbšie preskúmanie tejto oblasti Speerovho diela. ${ }^{5}$

Podla rôznych, aj sekundárnych správ Speer vydal šest’, resp. až sedem tlačených zbierok s hudbou na nemecké a latinské duchovné texty, pokrývajúcou hudobnú zložku liturgie evanjelickej konfesie na celý cirkevný rok viacerými druhmi sakrálnej hudby. ${ }^{6}$ Väčšinou sú to motetá, resp. duchovné koncerty na biblické texty a ich parafrázy, ale aj na pôvodnú dobovú duchovnú poéziu v nemeckom a latinskom jazyku, no k jeho tvorbe pre cirkevné potreby treba priradit aj dva kancionály s nemeckými duchovnými piesňami a ich úpravami so sprievodom klávesového nástroja. ${ }^{7}$ Speer nekomponoval diela pre velké vokálno-inštrumentálne obsadenie, ale uprednostňoval malé obsadenie 1-3 sólových hlasov sprevádzaných malou inštrumentálnou skupinou. Reagoval tak na oblúbený druh malého duchovného koncertu, ktorý sa po svojom zrode na prelome 16. a 17. storočia v Taliansku rýchlo rozšíril aj do zaalpských oblastí. Tu sa udržal až do konca 17. storočia, pokým sa nepretransformoval do novšej podoby tektonicky uzavretejšej a rozsiahlejšej duchovnej kantáty.

Philomela angelica cantionum sacrarum má medzi Speerovými zachovanými zbierkami sakrálnej viachlasnej hudby osobitné miesto. Všetkých dvadsaťštyri duchovných koncertov zhudobňuje iba latinské texty, zatial' čo ostatné jeho tlačené zbierky so sakrálnou hudbou sú zhudobnením bud' čisto nemeckých textov alebo miešajú latinské a nemecké textové zdroje. Univerzálny obsah zbierky z hladiska jazykového korešponduje aj s univerzálnostou tematického zamerania textov, ktoré sú vhodné pre liturgickú a náboženskú prax luteránov aj katolíkov.

Rok vydania zbierky spadá do čias Speerovej najväčšej publikačnej činnosti, teda do 80tych rokoch 17. storočia. Philomela angelica je v poradí štvrtým titulom sakrálnej hudby, na titulnom liste je datovaná rokom 1688. V tom istom roku Speer vydal aj Hudobného tureckého Eulenspiegela a dodnes nezachované zhudobnenia nemeckého prekladu poézie Bernarda z Clairvaux. O rok skôr vyšla jeho prvá verzia hudobno-teoretického traktátu.

Philomela angelica sa vo viacerých nekompletných exemplároch zachovala v slovenských archívoch, preto lákala k štúdiu viac ako iné Speerove zbierky sakrálnej hudby. Realizácia 8-zväzkovej kriticko-pramennej edície, ${ }^{8}$ na ktorej spolupracujem s kolegom Petrom Zajíčkom, je vyústením nášho dlhodobejšieho záujmu o tento prameň. Vd’aka naštudovaniu niekol'kých skladieb Petrom Zajíčkom s jeho súborom starej hudby Musica

5 Základné poznatky zverejnil MOSER, Hans Joachim. Daniel Speer als Dichter und Musiker. In: Musik in Zeit und Raum. Berlin: Merseburger, 1960, s. 119-144.

6 Musicalisches ABC, oder Auserlesene Sprüche der Heiligen Schrift, 1671, stratené; Evangelische Seelengedanken, I. - II., Stuttgart 1681, Ulm 1682; Philomela angelica cantionum sacrarum, 1688; Süsse Jesus-Freund, oder Jubilum S. Bernhardi, Stuttgart 1688, stratené; Jubilum coeleste, ... in lateinischen und teutschen Texten, Stuttgart 1692; ? Echo coelestis (avizované v Kleeblatte, nie je známe, či aj vypublikované).

7 Neuvermehrtes Würtembergisches Gesangbuch, Stuttgart 1691; Choral Gesang-Buch auff das Clavir oder Orgel, Stuttgart 1692. Zoznam Speerovej hudobnej a literárnej tvorby najkomplexnejšie publikoval MOSER, H. J. Daniel Speer.

8 Doteraz vyšli 2 zväzky z pripravovanej série. 
Aeterna sa Philomela angelica v posledných rokoch dostala aj na koncertné pódiá v obnovenej premiére a utvrdila v presvedčení, že jej obsah si pozornost́ zaslúži oprávnene. Štúdium zbierky prinieslo prekvapivé výsledky a vyvolalo mnoho otázok, týkajúcich sa okolností jej vzniku, distribúcie i dobovej recepcie. Na viaceré otázky sa podarilo už nájst' uspokojivé odpovede, ale niektoré ostávajú stále otvorené. Tento text priblíži aspoň niektoré aspekty, ktoré zbierku robia zaujímavým a v istom ohlade i jedinečným príkladom, akými rôznorodými spôsobmi a cestami sa v priebehu 17. storočia šírili talianske hudobné podnety do zaalpských regiónov.

1. Rébusy titulného listu zbierky. Speer Philomelu angelicu vydal pod pseudonymom - anagramom RES PLENA DEI (= Daniel Speer). Ukrývanie mena do rôznych slovných hračiek nebolo pre neho ničím neobvyklým, robil tak rád, i ked’ nevieme zodpovedat’ otázku, či ho k tomu viedli následky angažovanosti v spoločensko-politickom živote ${ }^{9}$ alebo dobová maniéra humanistického vzdelanca potrápit mysle svojho okolia nejakým rébusom. Identita autora, skrývajúceho sa za anagramom, je už v hudobnohistorickej literatúre známa dávnejšie, ale doteraz nie je uspokojujúco vyriešená otázka lokácie vzniku tlače. Miesto vydania alebo vytlačenia zbierky, tak, ako je uvedené na titulnom liste (obr. 1) - Venetiis - nie je reálne, čo podporuje aj fakt, že na ňom chýba meno tlačiara. Na otázku, prečo Speer uviedol fingovaný údaj môže byt viacero odpovedí. Benátky boli v 16.-17. storočí jedným z najvýznamnejších európskych centier hudobného vydavatelstva, v meste pôsobilo viacero známych a vyhladávaných oficín (Gardano, Vincenti), a tak punc benátskej tlače, či už reálny alebo fingovaný, mohol zvýšit jej komerčný úspech. Druhý dôvod môže súvisiet’ s obsahom samotnej zbierky, ktorej hlbšie preskúmanie odhalilo, že nie je celá pôvodným Speerovým dielom, čo naznačuje aj čast̉ textu titulného listu, ktorú uvádzame nižšie. Ďalšiemu bádaniu v otázke miesta vzniku zbierky môže pomôct̉ signum s menom Johanna Ulricha Krausa, ktoré sa nachádza v pravom dolnom rohu frontispicu partu pre basso continuo (obr. 2). Kraus bol augsburský rytec, ktorý začal svoju profesionálnu kariéru vo Viedni a po prestahovaní do Augsburgu sa z neho stal významný grafik, vydavatel a tlačiar obdobia prelomu 17. a 18. storočia. ${ }^{10}$ Frontispice nepatrí medzi Krausove známe diela, pravdepodobne vznikol v ranom období jeho tvorby, možno na základe nejakej staršej grafiky. V porovnaní s deklarovanými Benátkami je Augsburg reálnejším miestom vytlačenia zbierky, prípadne zbierka mohla výjst z inej nemeckej oficíny niektorého d'alšieho nototlačiarskeho centra blízko Speerovho vtedajšieho pôsobiska v Göppingene. ${ }^{11} \mathrm{Na}$ jednom exemplári zbierky,

9 Práve v roku publikovania Philomely bol Speer uväznený na pár mesiacov za zverejnenie letáku podnecujúceho k rebélii voči pasivite vrchnosti, nedostatočne brániacej krajinu proti vpádu francúzskej armády do württemberského kniežactva. Bližšie napríklad v MOSER, H. J. Daniel Speer.

10 SCHWInGEnSTEIN, Christoph. Kraus, Johann Ulrich. In: Neue Deutsche Biographie 12 [online]. 1979 , s. 689, [cit. 14. 7. 2016]. Dostupné z: http://www.deutsche-biographie.de/pnd100811833.html

11 BARTOVÁ, Jana. Philomela angelica Daniela Speera ako hudobno-historický, interpretačný a edičný problém. In: Quo vadis musica aeterna? Zborník príspevkov z muzikologickej konferencie, Bratislava, 24. september 2013. Bratislava: Orman, 2013, s. 22-28. 
ktorý sa našiel v pozostalosti francúzskeho hudobného teoretika Sébastiana de Brossarda, známeho obdivovatela a zberatela hudby talianskych skladatelov, je uvedená rukopisná poznámka „Brossard. P. Argentinum, Partes 7“. V Štrasburgu v tom čase ale bola nototlač v útlme, ${ }^{12}$ preto poznámka môže zavádzat'. Do úvahy prichádzajú aj d’alšie blízke centrá, kde sa tlačili noty, a to Stuttgart, prípadne Ulm, ale zdá sa, že ani v týchto mestách v danom čase neboli také dobré podmienky na tlačenie umeleckej hudby ako v Augsburgu. ${ }^{13}$

2. Problém autorstva obsahu zbierky. Skúmanie jednotlivých skladieb viedlo k zisteniu, že zbierka nie je úplne Speerovým dielom. Tento fakt je naznačený v časti textu titulného listu, ktorý dostal až dodatočne svoj význam a vniesol d’alšie otázky súvisiace s jeho interpretáciou. Uvádza sa v ňom: „Philomela angelica alebo duchovné piesne (cantiones sacrae), ktoré pred nejakým časom v Ríme zaspievala istá panna oddaná Bohu z rádu sv. Kláry jedným hlasom s bassom continuom a sama autorka ich vraj odspievala s nadprirodzeným pôvabom a jemnostou $k$ pocte svätosti, teraz $k$ ziskaniu väčšjej priazne a božskej úcty posledné rozšírenie - pridané štyri violy až dielko vzrástlo k správnej vel'kosti, 12 ECCE, s tromi hlasmi (alt, tenor, bas) a dvoma huslami s pridaným zdvojeným bassom continuom [...]." Speer urobil narážku na nemenovanú pannu hudobníčku aj na inom mieste a iným spôsobom. Je ním už spomínaný Krausov frontispice v parte pre basso continuo, na ktorom je vyobrazená mníška odetá v rúchu príslušníčok rádu sv. Kláry. Mníška hrá na organe a z jej úst vychádza nápisová páska s textom, parafrázujúcim biblické slová, ktorými odpovedala Panna Mária na anjelovo zvestovanie (Ecce ancilla Domini, psallam Deo meo quam diu sum). Kto bola táto Speerom obdivovaná mníška? Komparáciou repertoára zbierky s inými prameňmi sme dospeli k zisteniu, že je ňou Chiara Margarita Cozzolani (1602-1676/78), žijúca od svojej ranej mladosti ako mníška, neskôr abatiša v kláštore benediktínok u sv. Radegundy v Miláne. ${ }^{14}$ Tu pôsobila aj ako uznávaná regenschori, hudobníčka a skladatel'ka. V 40-tych rokoch 17. storočia vydala štyri tlačené hudobné zbierky: Primavera di fiori musicali, 1640, Concerti sacri, 1642, Scherzi di sacra melodia, 1648 a Salmi a otto voci concertati, 1650, ktoré okrem prvej, milánskej tlače, všetky vyšli v Benátkach. ${ }^{15}$ Speer do svojej Philomely určite prevzal 6 skladieb zo zbierky sólových motet Scherzi di sacra melodia, ale nie je vylúčené, že aj d’alších 6 skladieb, vzhl’adom na isté špecifické hudobné a textové charakteristiky, je prevzatých. Do úvahy ako zdroj prichádza jedine prvý

12 PRZYWECKA-SAMECKA, Maria. Drukarstwo muzyczne w Europie do końca XVIII wieku. Wrocław: Ossolineum, 1987, s. 194.

13 Moser predpokladal tlač zbierky v Ulme alebo v Norimbergu. MOSER, H. J. Daniel Speer, s. 136. Porovnaj BARTOVÁ, J. Philomela angelica, s. 24-25.

14 Hudobnou kultúrou Milána v 17. storočí a rolou ženských kláštorov na jej formovaní sa najnovšie zaoberá v svojich dvoch monografiách KENDRICK, Robert L. Celestial Sirens: Nuns and their Music in Early Modern Milan. Oxford: Clarendon Press, 1996; Týž. The Sounds of Milan, 1585-1650. Oxford: Oxford University Press, 2002. Zároveň publikoval pramenno-kritickú notovú edíciu kompletne zachovanej časti diela Ch. M. Cozzolaniovej.

15 Pozri úvodnú štúdiu editora pramenno-kritickej notovej edície KENDRICK, Robert L. Introduction. In: Chiara Margarita COZZOLANI: Motets. Robert L. Kendrick (ed.). Madison, Wis.: A-R Editions, 1998, s. IX. 
opus - Primavera di fiori musicali - ten sa ale nezachoval v žiadnom exemplári. Druhá polovica zbierky - 12 „Ecce“-motet pre jednotné obsadenie trojice sólových hlasov sprevádzaných dvoma huslami je bez pochýb Speerovým originálnym dielom. Zarážajúce je, že v narážke na nemenovanú pannu hudobníčku v texte titulného listu sa Speer dopustil nezrovnalosti, ked' ju označil za členku rádu klarisiek v Ríme. Nevieme, či tak urobil naschvál, aby opät využil svoju zálubu vo vytváraní hádanok a stavaní prijímatel’a svojho diela pred riešenie rébusov, alebo z nevedomosti a poznania diela Cozzolaniovej iba sprostredkovane. Cozzolaniová po vstupe do rádu benediktínok prijala rehol'né meno Chiara a symbolická spojitosṫ so sv. Klárou a rádom klarisiek mohla byt’ narážkou na túto súvisloste. V Miláne ale mali klarisky v 17. storočí založené 3 kláštory, ${ }^{16}$ a preto spojenie účinkovania Cozzolaniovej s rádom klarisiek v Ríme sa zdá byt len dôsledkom Speerovej zlej informovanosti.

3. Recepcia tvorby Cozzolaniovej v zaalpských regiónoch. Napriek tomu, že Cozzolaniová publikovala iba 4 hudobné zbierky v pomerne úzkom časovom rozpätí 10 rokov, jej tvorba sa stala známou a rozšírenou nielen v severotalianskych hudobných centrách ale aj za Alpami a v repertoári sa udržala pomerne dlho, lebo okrem prvej zbierky sa jej tlače objavovali v katalógoch Vicentiho ponuky hudobných tlačí aj v 60-tych rokoch 17. storočia. ${ }^{17} \mathrm{~V}$ zaalpských krajinách bola jej tvorba známa najmä na luteránskych nemeckých chóroch. K tomuto paradoxu prispel asi aj fakt, že 7 rokov po vydaní zbierky Concerti sacri, nemecký editor Ambrosius Profius zaradil do jednej zo svojich populárnych antológií modernej talianskej hudby, Corollarium geistlicher Collectaneorum z roku 1649, aj jedno moteto z tejto zbierky, ktoré pravdepodobne vyvolalo záujem aj o jej d’alšie diela. Išlo o skladbu O dulce Jesu pre dva soprány a basso continuo, ktorá neskôr cirkulovala v odpisoch pravdepodobne $\mathrm{z}$ tohto zdroja. Jeden odpis sa vraj nachádza aj v nemenovanom českom archíve, a to s pridanými partami dvoch huslí. ${ }^{18}$ Odpisy iných skladieb sú dokumentované v Ansbachu, ${ }^{19}$ Paríži, ${ }^{20}$ dokonca aj v Bolívii, ${ }^{21}$ niekedy pod menom iného skladatela (Carissimi, Zipoli). Nás ale najviac zaujímalo, akými cestami mohol spoznat tvorbu Chiary Margarity Cozzolani Daniel Speer. Odpovedat’ na ňu nie je jednoduché, pretože v Speerovej biografii je viacero otáznikov.

Prvý kontakt s tvorbou Cozzolaniovej mohol poskytovat’ už Speerov pobyt na gymnáziu Márie Magdalény v jeho rodisku. Mesto Wrocław bolo významným centrom hudob-

\footnotetext{
16 KENDRICK, R. L. Celestial Sirens, s. 17.

17 Tamtéž, s. 302.

18 Informácia podla KENDRICK, R. L. Introduction, s. XV.

19 SCHAAL, Richard. Die Musikhandschriften des Ansbacher Inventars von 1686. Wilhelmshaven: Heinrichshofen's Verlag, 1966, s. 42; KENDRICK, R. L. Celestial Sirens, s. 375.

20 Tamtéž.

21 Concepción (Ñuflo de Chávez), Archivo Musical de Chiquitos, Sa33 (olim Inventario 4). Informácia podla KOLDAU, Linda Maria. Chiara Margarita Cozzolani. In: BORCHARD, B., ed. Musikvermittlung und Genderforschung: Lexikon und multimediale Präsentationen. [online]. Hochschule für Musik und Theater, 2003 [cit. 14.7. 2016]. Dostupné z: http://mugi.hfmt-hamburg.de/A_lexartikel/lexartikel.php?id=cozz1602
} 
ného života, organizovaného viacerými hudobnými inštitúciami. ${ }^{22} \mathrm{O}$ ich hudobných záujmoch svedčí dodnes zachovaná rozsiahla zbierka hudobných tlačí a rukopisov, ${ }^{23} \mathrm{v}$ ktorej sa nachádzajú aj kompletné alebo nekompletné exempláre všetkých Cozzolaniovej tlačených zbierok, s výnimkou prvého opusu. Nevieme, kedy sa exempláre tlačí do Wrocławu reálne dostali; ak ich sliezski hudobníci zadovážili expresne rýchlo, mohli sa teoreticky Speerovi dostat do rúk ešte pred opustením mesta najneskôr roku 1650. O d'alších životných osudoch Speera existujú len hmlisté informácie, aké uvádza prostredníctvom svojej cestopisnej trilógie, ktorá popri mnohým prevzatým informáciám encyklopedického charakteru vykazuje aj znaky autentickosti a osobných skúseností. ${ }^{24}$ Ak teda uveríme tomu, čo Speer napísal vo svojom autobiografickom románe Uhorský alebo dácky Simplicissimus, po odchode z rodného mesta sa šest’ rokov pohyboval na území stredného a východného Slovenska, vtedy Horného Uhorska, kde ako vandrujúci študent navštívil viacero miest, známych svojimi dobrými latinskými školami. Ako uvádza v svojom románe, počas tohto pobytu sa zoznámil so životom v Levoči, Kežmarku, Sabinove, Košiciach, Prešove. Všetky menované mestá boli nielen centrami vzdelávania ale aj rozvinutého hudobného života. Speer tu teda mohol získat aj praktické skúsenosti hudobníka; ako študent latinskej školy bol iste zapojený do spolupráce medzi školou, cirkvou a mestskou samosprávou na zabezpečovaní hudby počas slávnostných bohoslužieb i v rámci iných oficiálnych verejných podujatí a podla vlastného svedectva prešiel aj výcvikom učňa u majstra trubača v Sabinove. Presné roky pobytu Speera na Slovensku nie sú známe, ale mohlo to byt niekedy v rozpätí rokov 1650-1660.

Speer po odchode z územia Slovenska d’alej cestoval, kým sa usadil vo Württembersku. Podla narážok v svojich románoch mohol strávit’ nejaký čas v Sedmohradsku ${ }^{25}$ a na území Osmanskej ríše, ale pobyt v Taliansku priamo ani nepriamo nespomína. Milánsky kláštor u sv. Radegundy, hlavne hudba predvádzaná počas verejných omší a ofícií tamojšími mníškami patrili v 17. storočí k turistickým atrakciám, ktoré si nenechal ujsţ žiaden návštevník mesta, či už prišiel z blízkeho okolia alebo vzdialenej krajiny,

22 JEŻ, Tomasz. The Italian Baroque Repertoire in St Elisabeth Church in Wrocław. In: Early Music. Context and Ideas II. International Conference in Musicology, Kraków, 11-14 September 2008. Kraków: Institute of Musicology, Jagiellonian University, 2008, s. 399-408; JEŻ, Tomasz. La diffusione del repertorio policorale dell Italia del nord nell'ambiente protestante della Slesia nel primo Seicento. In: PATALAS, A., TOFFETTI, M., ed. La musica policorale in Italia e nell 'Europa centro-orientale fra Cinque e Seicento. Venezia: Fondazione Ugo e Olga Levi, 2012, s. 215-228.

23 BOHN, Emil. Bibliographie der Musik-Druckwerke bis 1700 welche in der Stadtbibliothek, der Bibliothek des Academischen Instituts fuer Kirchenmusik und der Koeniglichen und Universitaets-Bibliothek zu Breslau aufbewahrt werden. Berlin: Commissions-Verlag von Albert Cohn, 1883, s. 106.

24 Editor kompletného slovenského prekladu prvej knihy z trilógie - Uhorský a či dácky Simplicissimus predkládajúci svoju podivnú životnú pút a zvläštne príhody, ktoré ho stretli na cestách, pričom pravdivo opisuje predtým kvitnúce a často znepokojované Uhorsko, jeho mravy, zvyky a rozličné vojny. Bratislava: SVKL, 1964 -, Jozef Vlachovič, v svojom epilógu ponúka viacero argumentov, prečo pobyt Speera na Slovensku treba považovat za pravdivý. Okrem iného sú to aj informácie autentickej povahy, ktoré nemohli byt̉ prevzaté zo žiadneho iného dobového diela.

25 Peter Király pri svojom výskume hudobného života na sedmohradských šlachtických dvoroch narazil na zmienku o istom „Sipos Daniel“, ktorý sa uvádza v aktách dvora sedmohradského princa Jána Keményho z roku 1661. Zatial' nie je jasné, či sa tento údaj vztahuje na Daniela Speera. Pozri bližšie KIRÁLY, Peter. Külföldi zenészek a XVII. századi erdélyi fejedelmi udvarban és hatásuk. Erdélyi Múzeum 1994, 56, no. 1-2, s. 15. 
ako o tom svedčia zápisy vysokopostavených osôb v návštevných knihách kláštora. ${ }^{26}$ Bol medzi nimi aj Speer? S prihliadnutím na mylné uvedenie spievajúcej mníšky ako členky rádu klarisiek v Ríme je táto možnost̉ len málo pravdepodobná. Speer ale, podla vyjadrenia v Uhorskom alebo dáckom Simplicissimovi, z Uhorska naspät na sever putoval cez Rakúsko, a teda je len málo pravdepodobné, že by obišiel hlavné mesto Královského Uhorska - Bratislavu (vtedy Pressburg, Posonium, Poszony, Prešporok), o to viac, ked' v tomto meste post kapelníka (directora musicae) evanjelického chrámu zastával Samuel Capricornus, starší spolužiak z vratislavského gymnázia. ${ }^{27} \mathrm{Na}$ chóre kostola sa nachádzala rozsiahla zbierka hudobnín, ktorú Capricornus ešte rozšíril nákupom talianskych hudobných tlačí s najnovšou tvorbou v koncertantnom štýle. ${ }^{28}$ Bol to práve on, kto zadovážil na chór zbierku žalmov Chiary Margarity Cozzolaniovej z roku 1650. ${ }^{29}$ Speer síce Bratislavu ako miesto osobnej návštevy nespomína, ale hudobníkom z ned’alekej Šoprone venoval svoju zbierku Recens fabricatus labor ${ }^{30}$ a ked' roku 1692 publikoval Choral-Buch, spevník nemeckých duchovných piesní s organovým sprievodom, k spevu trópovaného Kyrie pripojil aj clausulu, za ktorej autora označil Samuela Capricorna, bratislavského a neskôr stuttgartského kapelníka. ${ }^{31}$

4. Dobová recepcia zbierky Philomela angelica. Speerova Philomela sa dodnes zachovala v 4 exemplároch. Ďalšie doklady o rozšírení zbierky poskytujú sekundárne hudobné pramene, akými sú inventáre zbierok hudobnín, ktoré sa dodnes nezachovali. Pozoruhodné je, že väčšina dokladov o rozšírení zbierky sa viaže na hudobné centrá z územia Slovenska. Dodnes sa zachovali nekompletné exempláre z hudobných zbierok piaristického kláštora v Podolínci a z farského kostola v Pruskom, ale podla inventárnych zoznamov hudobnín ju mali k dispozícii aj hudobníci u piaristov vo Svätom Jure (1696) a nachádzala sa aj na chóre nového

26 KENDRICK, R. L. Celestial Sirens, s. 102 an.

27 Podl’a výskumov Barbary Przybyszewskej-Jarmińskej sa Capricornus uvádza medzi prijatými študentami v roku 1644 (Wrocław, Archiwum Państwowe, Akta Miasta Wroctawia, sign. 5175 / olim P 141,1: Aufnahmebücher (Matricularie) des Mariae Magdalenae Gymnasium 1617-1666, s. 281).

28 KALINAYOVÁ, Jana a kol. Hudobné inventáre a repertoár viachlasnej hudby na Slovensku v 16.-17. storoči. Bratislava: Slovenské národné múzeum-Hudobné múzeum, 1994, s. 47-50. V inventárnych zoznamoch hudobnín evanjelického a.v. kostola z roku 1651 a 1652 Capricornus presne špecifikoval, ktoré hudobniny obstaral on.

29 Tamtéž, s. 48, číslo [125].

30 Dielo je dedikované 4 znamenitým cinkenistom pôsobiacim v okolí Stuttgartu ako aj d’alším osobám, ktorým sa Speer v úvode partu bassa continua prihovoril osobitne veršami. Jedným z takto oslovených je aj „Lorencz Bessler / Musicus Instrum. Ordinarius in Ungarischem Oedenburg“. Bessler pochádzal z Wrocławu a v Šoproni pôsobil ako mestský trubač a inštrumentalista. Ďalšiu spojitost́ hudobníkov Šoprone so Speerovou tvorbou poskytuje Starckova virginálová kniha, ktorú napísal šoproňský hudobník Johann Wolmuth. V zbierke sa nachádza aj niekol'ko skladieb prevzatých bud' z Musicalisch Türckischer Eulenspiegel alebo hudobno-teoretického kompendia Daniela Speera. Pozri bližšie FERENCZI, Ilona. Sopron in the 17th Century [Úvodná štúdia k pramenno-kritickej edícii]. In: FERENCZI, I., ed. Starck Virginal Book (1689) Compiled by Johann Wohlmuth - Johann Wohlmuth Miserere (1696). Budapest: Magyar Tudomanyos Akademia MTA, s. 100, 114.

31 Choral Gesang-Buch, Auff das Clavir oder Orgel, Worinen aller brauchbaren Kirchen- und Haus-Gesängen eigene Melodeyen, in Noten-Satz mit 2. Stimmen, als: Discant und Bass untereinender: Neben einen Anhang vieler Auserlesener Arien... Stuttgart 1692, číslo 235: Variatio dieser letzter clausul, Authore Sam. Capricorno. Pozri aj MOSER, H. J. Daniel Speer, s. 134. 
evanjelického kostola v Bratislave (1718). ${ }^{32}$ Zdá sa, že na území Slovenska mala táto zbierka nezvyčajne intenzívny ohlas. Boli príčinou takého vel'kého rozšírenia Philomely kontakty, ktoré Speer nad’alej so Slovenskom udržiaval a o ktorých zatial' nič nevieme, alebo je to výsledok rovnakých distribučných kanálov obchodníkov s hudobninami? Ked’že sa v dobových inventároch hudobnín zbierka uvádza vždy iba anonymne, pravdepodobnejšia je druhá možnost'. Z údajov v hudobných inventároch z poslednej tretiny 17. storočia d’alej vyplýva, že okrem benátskych nototlačí sa do hudobných centier na Slovensku dovážali najmä nototlače z tlačiarní južného Nemecka, predovšetkým z Augsburgu, ktorý považujeme za potenciálne miesto reálneho vytlačenia zbierky. Druhým faktorom, zabezpečujúcim široké uplatnenie zbierky, bol jej obsah, ktorý z náboženského hladiska umožňoval predvedenie diel tak v luteránskom, ako aj v katolíckom obrade. Anonymita diela k širšiemu ohlasu mohla len dopomôct', lebo meno luteránskeho autora by mohlo niekoho v časoch vrcholiacich náboženských sporov v katolíckom prostredí odradit'. Paradoxné je, že o žiadnom inom Speerovom diele nemáme takéto jasné dôkazy dobového ohlasu na Slovensku ako v prípade zbierky Philomela angelica. To, že sa zbierka prakticky využívala, dokladá exemplár z piaristického kláštora v Podolínci, kde v parte pre basso continuo sú v indexe opravené tlačové chyby v uvedení obsadenia a pri každej skladbe sa nachádzajú rukopisné poznámky udávajúce liturgickú príležitost’, pre ktorú bola tá-ktorá skladba vhodná na predvedenie.

V repertoári hudobných centier 17. storočia v Čechách a na Morave, ako sa zatial' ukazuje, nemali Philomela angelica a ani iné diela Daniela Speera žiadnu odozvu. Nie je zatial jasné, či pät rukopisov s tanečnou hudbou, signovaných menom „Speer“, ktoré sa nachádzajú vo fondoch Národního muzea - Českého muzea hudby v Prahe, môže nejako súvisiet’ s potomkami Daniela Speera. Je známe, že Georg Daniel pokračoval ako kantor a hudobník v otcových stopách v svojom rodisku, v Göppingene a mladší syn, Johann Georg sa prestahoval do Čiech. ${ }^{33}$

5. Modely a ich neskoršie aranžmány. Aranžovanie Cozzolaniovej skladieb skladatel’om mladšej generácie s odstupom 3-4 desatročí podnecuje k zamýšlaniu sa, ako sa zmenil za toto obdobie hudobný vkus. V súlade s tendenciami v inštrumentácii vokálnych skladieb ku koncu 17. storočia Speer k sólovému hlasu pridal väčší nástrojový sprievod 4 sláčikových nástrojov, čím dosiahol hutnejší, farebnejší zvuk. Častým vsúvaním inštrumentálnych medzihier zároveň oslabil silný kontrast medzi jednotlivými pasážami, ktorý je charakteristickým znakom milánskeho moteta 40-tych rokov 17. storočia a ktorého významnou reprezentantkou bola práve Chiara Margarita Cozzolaniová. ${ }^{34}$ Vsunuté inštrumentálne sekvencie zároveň vnútorne predížili jednotlivé kontrastujúce pasáže, takže celkove Speerove adaptácie v porovnaní s pôvodnými Cozzolaniovej verziami nepôsobia až tak

32 KALINAYOVÁ, J. a kol. Hudobné inventáre, s. 135, č. 660, s. 139, č. 5, s. 144, č. 5, s. 160, č. 21.

33 MOSER, H. J. Daniel Speer, s. 141.

34 KENDRICK, R. L. Celestial Sirens, s. 304-414. 
„hranato“ a nadobúdajú väčšiu homogénnost,, koncíznost', i ked’ nie v takej miere, ako kantátová tvorba komponovaná koncom storočia. Pravdepodobne tento trend mal Speer na mysli, ked' na titulnom liste zdôvodňoval svoje úpravy slovami „aby dielko vzrástlo k správnej vel'kosti“.

6. Regionálne inštrumentačné špecifiká. Speerove aranžmány dávajú príležitosṫ zamysliet’ sa aj nad regionálnymi špecifikami inštrumentácie. V čase, ked’ Taliani už úplne prešli na violinové typy sláčikových nástrojov, na severe ešte stále boli bežne nasadzované violy da gamba. Speer v tomto urobil kompromis. Sopránové polohy obsadil typicky taliansky, teda dvojicou huslí, ale altovú a tenorovú polohu plniacu funkciu harmonickej a zvukovo farebnej výplne, mohli hrat nešpecifikované sláčikové nástroje, teda violy da braccio a violončelá, ale aj violy da gamba. Je viacero dokladov o tom, ako skladatelia menili prípadne modernizovali inštrumentáciu skladieb podla regiónu, zvyklostí a možností prostredia, v ktorom sa nachádzali. Zdá sa napríklad, že na württemberskom dvore v Stuttgarte bol ako inštrumentálny sprievod vokálnych hlasov oblúbený matnejší zvuk gámb. ${ }^{35}$ Speer na titulnom liste svojej zbierky spomína, že motetá neznámej mníšky rozšíril a „doplnil o 4 violy“, pričom v svojom hudobno-teoretickom kompendiu pripúšta možnost’ substitúcie viol da braccio a da gamba. ${ }^{36}$ Dnešný interpret tak má volnú ruku výberom nástrojových typov priklonit sa viac $\mathrm{k}$ talianskej alebo severonemeckej inštrumentačnej praxi. ${ }^{37}$

7. Speerove hudobné inšpirácie. Speerove originálne skladby z Philomely angeliky dávajú možnoste študovat, ako si Speer osvojil taliansky koncertantný štýl a v čom ho mohla tvorba Chiary Margarity Cozzolaniovej tak inšpirovat', že sa rozhodol vzdat jej hold v jednej zo svojich zbierok. Z doterajších poznatkov zo štúdia Speerovej sakrálnej koncertantnej tvorby možno vplyv Cozzolaniovej kompozičného štýlu vidiet v Speerovej invenčnej, kantabilnej melodike tanečného typu, ale aj vo výrazovosti, dosahovanej často vzrušeným, nástojčivým opakovaním významove dôležitých slov a vo využívaní páuz na dosiahnutie želaného afektu. Speer v svojom kompendiu odporúča, že ak chce byt hudobník dobrým skladatel'om, „musí mat' dobrú invenciu na prirodzené melódie, lebo tie sa nedajú naucit", ale mal by aj „prepisovat' skladby dobrých autorov do partitúry: z toho uvidi a nauči sa nejeden spôsob postupu. Obohatenie prináša aj cestovanie a počúvanie dobrej hudby i diskutovanie o nej. " Speer tieto rady podla všetkého dával z vlastnej skúsenosti.

35 Samuel Capricornus, ktorý počas svojho bratislavského pobytu skomponoval cyklus duchovných koncertov na poéziu sv. Bernarda z Clairvaux Jubilus Bernhardi so sprievodom dvoch huslí skladby po príchode do Stuttgartu reinštrumentoval sprievod z dvoch huslí na 4 bližšie nešpecifikované violy.

36 SPEER, Daniel. Grundrichtiger Kurtz-Leicht-und Nöthiger jetzt Wol-vermehrter Unterrich der Musicalischen Kunst. Oder Vierfaches Musicalisches Kleeblatt. Ulm 1697, s. 199. Pozri aj BARTOVÁ, J. Philomela angelica, s. 28.

37 Musica Aeterna interpretuje skladby s violinovými typmi nástrojov, zatial' čo v nahrávke Capelly Artemisia Scintillate amicae stellae (Tactus, 2011, TC 2800003) je pri uvedení skladby O praeclara dies použitý súbor štyroch gámb. 


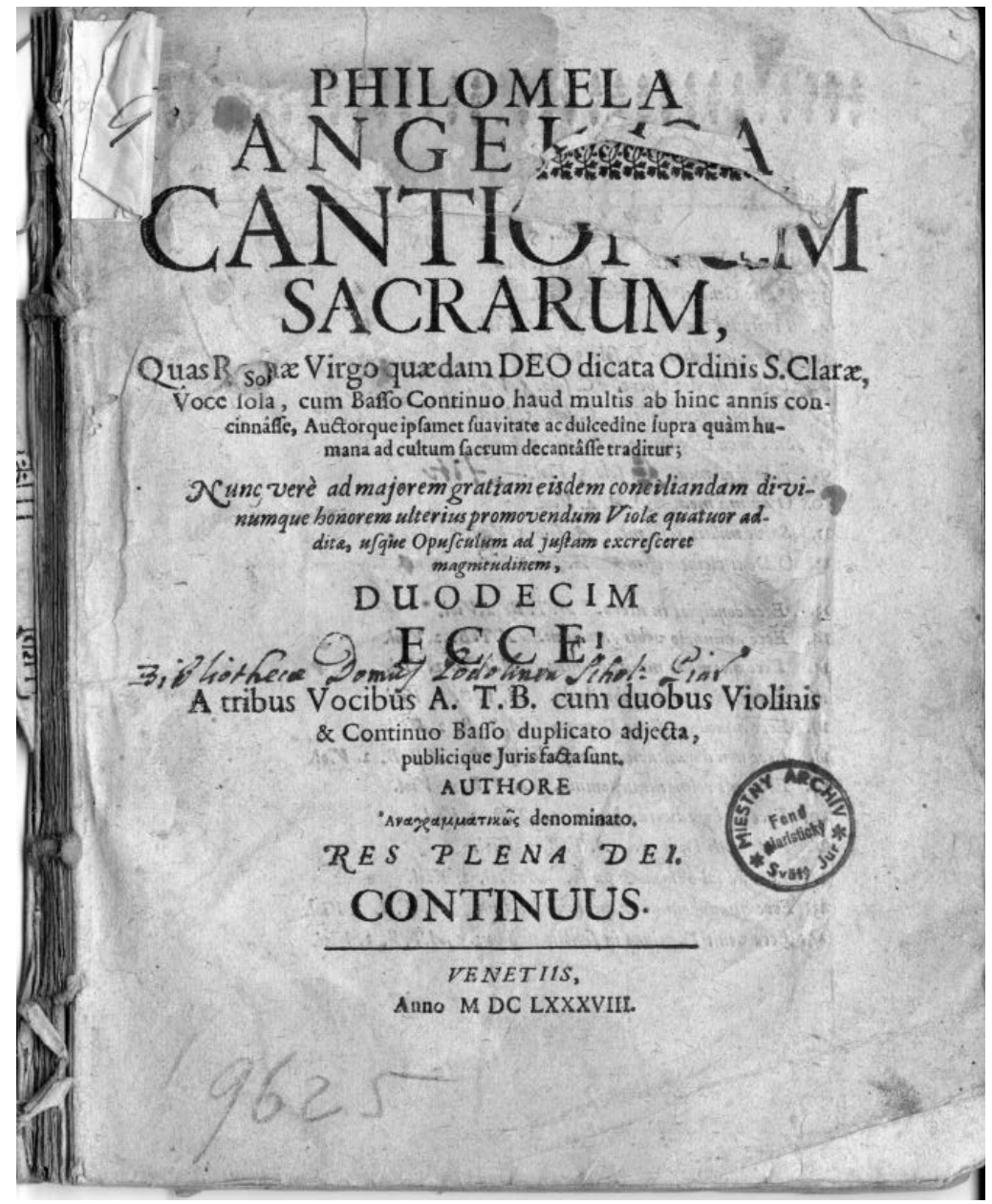

Obr. 1. Titulný list zbierky Philomela angelica Daniela Speera z exemplára zachovaného v zbierke hudobnín z piaristického kláštora v Podolínci. 


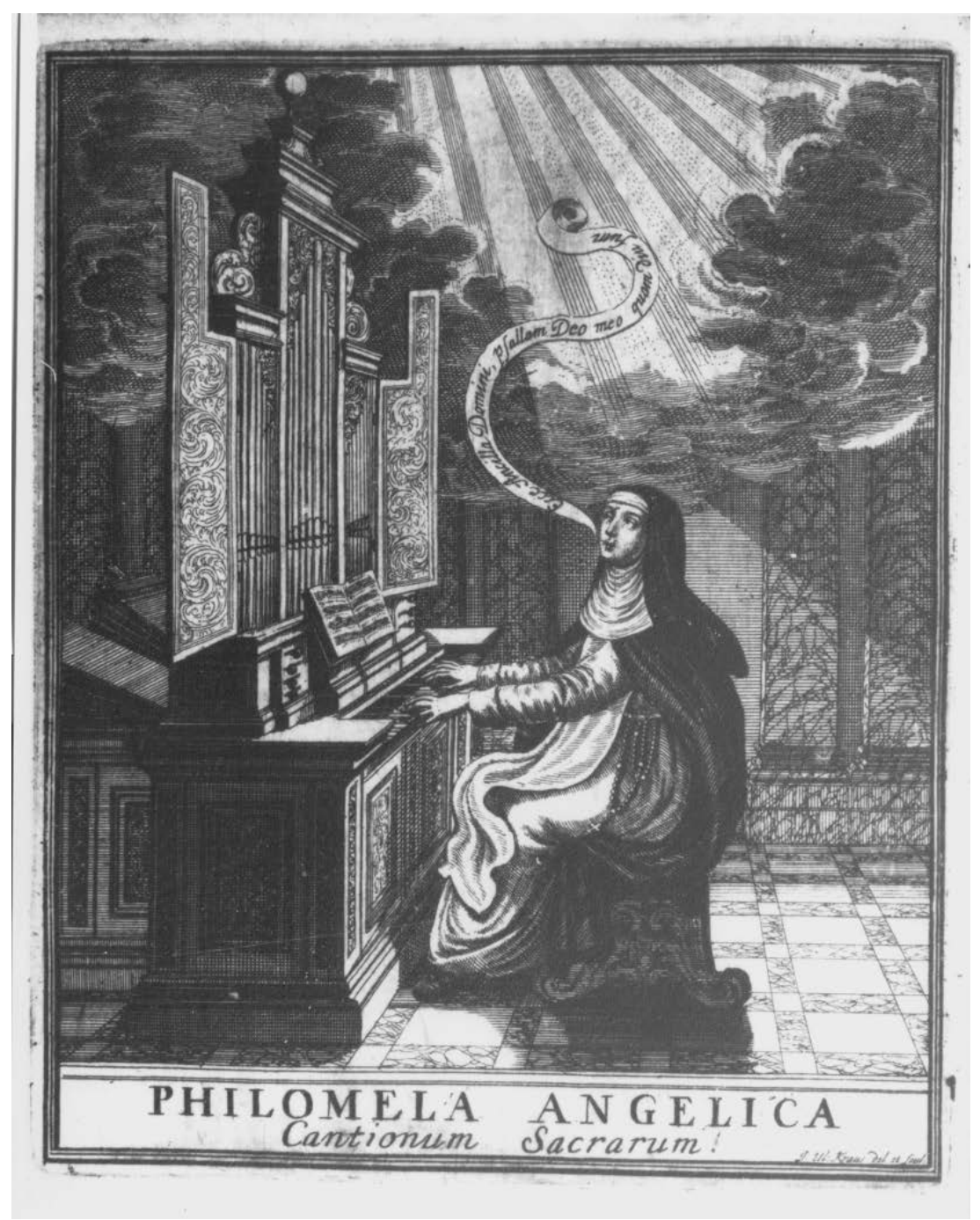

Obr. 2. Frontispice v parte pre basso continuo. 
Táto práca bola podporená Agentúrou na podporu výskumu a vývoja na základe Zmluvy č. APVV-14-0681 a agentúrou VEGA v rámci projektu 1/0850/14.

\section{Bibliography}

BARTOVÁ, Jana. Philomela angelica Daniela Speera ako hudobno-historický, interpretačný a edičný problém. In: Quo vadis musica aeterna? Zborník príspevkov z muzikologickej konferencie, Bratislava, 24. september 2013. Bratislava: Orman, 2013, s. 22-28.

KALINAYOVÁ, Jana a kol. Hudobné inventáre a repertoár viachlasnej hudby na Slovensku v 16.-17. storoči. Bratislava: Slovenské národné múzeum-Hudobné múzeum, 1994, 244 s. ISBN 80-85753-23-5.

KALINAYOVÁ-BARTOVÁ, Jana, 2014. Daniel Speer a jeho Philomela angelica cantionum sacrarum. In: Kalinayová-Bartová, J., Zajíček, P., eds. Daniel Speer (1636-1707): Philomela angelica cantionum sacrarum (1688), Musicalia Istropolitana 7/5. Bratislava: Ars Musica, s. IX - XXX. ISBN 978-80-971672-0-2.

KALINAYOVÁ-BARTOVÁ, Jana. Talianske hudobné inšpirácie v zbierke Philomela angelica Daniela Speera. In: KALINAYOVÁ-BARTOVÁ, J., ZAJÍČEK, P., eds. Daniel Speer (1636-1707): Philomela angelica cantionum sacrarum (1688), Musicalia Istropolitana 7/1. Bratislava: Ars Musica, 2016. ISBN 978-80-971672-1-9.

KENDRICK, Robert L. Celestial Sirens: Nuns and their Music in Early Modern Milan. Oxford: Clarendon Press, 1996, 556 s. ISBN 0-19-816408-4.

MOSER, Hans Joachim. Daniel Speer als Dichter und Musiker. In: Musik in Zeit und Raum. Berlin: Merseburger, 1960, s. 119-144. 
